\title{
Successful Therapy on Patients with Yolksac and Embrional Carcinoma by Surgery and Chemotherapy
}

\author{
Fahmi Adhi Prasetya', Susanthy Djajalaksana ${ }^{1}$, Diah Prabawati Retnani', Artono Isharanto ${ }^{3}$, \\ Indrastuti Normahayu ${ }^{4}$, Shinta Okta ${ }^{5}$ \\ ${ }^{1}$ Pulmonology and Respiratory Medicine Department, Saiful Anwar General Hospital, Universitas Brawijaya \\ ${ }^{2}$ Pathology Anatomy Department, Saiful Anwar General Hospital, Universitas Brawijaya \\ ${ }^{3}$ Thoracic and Cardiovascular Surgery Department, Saiful Anwar General Hospital, Universitas Brawijaya \\ ${ }^{4}$ Radiology Department, Saiful Anwar General Hospital, Universitas Brawijaya \\ ${ }^{5}$ Internal Medicine Department, Saiful Anwar General Hospital, Universitas Brawijaya
}

\begin{abstract}
Background: Malignant mixed germ cell tumors account for 13-25\% of all non seminoma germ cell tumors, almost all cases were found in males $(85 \%)$, increased in the third decade, and had an average survival rate of $40-45 \%$. With modern management the average 5 -year survival rate can be over $80 \%$.

Case Report: We reported a case report in Saiful Anwar Malang Hospital, Indonesia, a young man, 26 years old with an malignant epithelial tumor derived from mediastinal or lung. The CT scan of the chest showed an lobulated solid mass of iso-hipodens on the anterior superior mediastinum, mass encompassing the aortic arch, left pulmonalis artery, subclavian artery. The result from transthoracic FNAB with USG guidance showed an malignant epithelial tumor derived from mediastinal or lung, impression of an adeno squamous carcinoma. The AFP, LDH, and NSE serum level was elevated. Patient underwent a surgical sternotomy and tumor debulking. The biopsy showed an malignant mixed germ cell tumor (yolksac and embrional carcinoma). These were confirming the diagnosis of malignant mixed germ cell mediastinal tumor (yolksac and embrinonal carcinoma). Patient received a combination bleomycin, etoposid, cisplatin 3 series chemoteraphy and evaluated.
\end{abstract}

Conclusion: Some procedures like biopsy, tumor marker, could differentiate the subtype of mediastinal germ cell tumor. The multimodality treatment by combining surgical therapy (surgical sternotomy and tumor debulking) with chemotherapy could increase the survival rate of patients.

Keywords: mixed germ cell tumour, surgical, chemoteraphy

MRJ 2020; 02(01):62-67

\section{Introduction}

Germ cell tumors only $2-5 \%$ of all

mediastinal tumors, but $50 \%-70 \%$ are

extragonadal tumors. ${ }^{1}$ Classification of

germ cell tumor divided into 3
Seminoma (yolk sac tumors, embryonal

carcinomas, choriocarcinomas and

mixed germ cell tumors). ${ }^{2}$ Germ cell

tumors are less frequent than the

thymoma, more often in males and

categories: Teratoma, Seminoma, Non-

\footnotetext{
${ }^{*}$ Corresponding author:
}

Fahmi Adhi Prasetya (fahmiadhi85@gmail.com)

Pulmonology and Respiratory Department, Saiful Anwar Hospital - Universitas Brawijaya, Jaksa Agung Suprapto St. No. 2, Malang.65112, Indonesia 
young adults. ${ }^{3}$ The average age of affected adults are 33 year for seminoma and 28 year for non seminoma germ cell tumor patients. ${ }^{3}$ The clinical symptoms of germ cell mediastinal tumors are chest pain $(52 \%)$, shortness of breath $(48 \%)$, cough (24\%), hoarseness (14\%), and superior vena cava syndrome $(14 \%) .{ }^{1}$ The thoracic CT scan showed an extent of disease, relationship to surrounding tissues, presence of cystic areas and tumor calcifications. ${ }^{4}$

In non seminoma germ cell tumors patients, high levels of b-hCG (30\%$50 \%$ of patients), high levels of AFP (60-80\% of patients) or high level of bhCG and AFP (80-85\% of patients) can occur. ${ }^{4}$ Histological finding in the malignant mixed germ cell tumor (yolksac and embrional carcinoma) is the Schiller-Duval bodies and Glandular growth pattern. ${ }^{1}$

The management of mixed germ cell tumors is Cisplatin-based modern chemotherapy and resection. After being given chemotherapy, the viability of non-teratoma tumors reaches up to $50 \%$, even after normalizing serum tumor markers. ${ }^{1}$

Patient with mixed germ cell tumor shows $40-45 \%$ survival rate, but the Cisplatin-based modern chemotherapy showed significant improvement. The 5 years survival rate more than $80 \%$ can be achieved with modern therapy. ${ }^{1}$

\section{Background}

This case report was published because of the rarity of mixed germ cell mediastinal tumors (yolksac and embrional Carcinoma). The multimodality diagnostic procedure and therapy need to be discussed with the multidiscipline team (MDT) to get the most suitable treatment for each patient. 


\section{Case}

Patient is male, 26 years old with chief complain left chest pain for 3 month, shorthness of breath and fever in the last 2 days and decreased of body weight $0,5 \mathrm{~kg}$ in a month. He didn't history of previous respiratory symptoms and didn't history of smoked cigarette. From the physical examination there were tachycardia (heart rate $102 / \mathrm{min}$ ), decreased of stem fremitus in the middle leftt chest, dullness in the middle left chest, and decreased of the breath sound in middle left chest. Thoracic CT scan with contrast in 2017 showed in Fig 1. The laboratory result showed leukocytosis $(22.720 / \mu \mathrm{L})$, AFP level was elevated to $1.480 \mathrm{ng} / \mathrm{mL}$ (normal range $0-20 \mathrm{ng} / \mathrm{mL}$ ), increased of LDH level $1136 \mathrm{U} / \mathrm{L}$ and $\beta$ HCG level within normal limit $(0,34$ $\mathrm{mIU} / \mathrm{mL}$ ). The bronchoscopy showed an compressive stenoting due to extralumenal urgency, possibly from mediastinal urgency. The cytology from transthoracic needle aspiration (TTNA) with ultrasound guiding showed a malignant epithelial tumors that can originate from the mediastinum or lung, suggest an Adeno Squamous Carcinoma (fig 2).

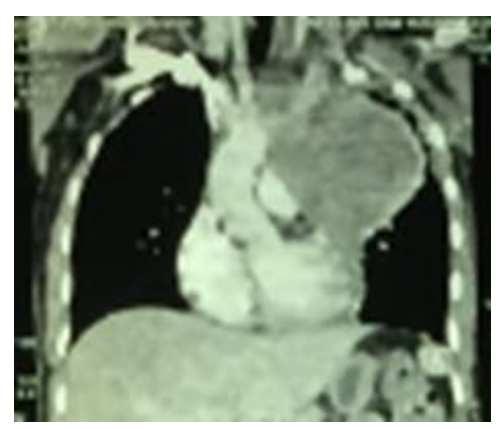

Coronal View

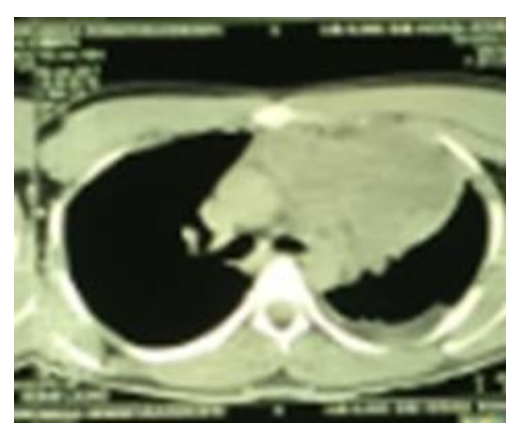

Axial View

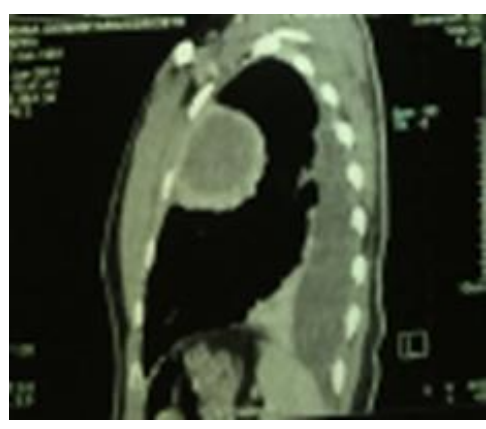

Sagital View

Figure 1. Solid mass lobulated edge measuring $\pm 17 \times 8 \times 10 \mathrm{~cm}$ in left anterior superior mediastinal mass. 


\section{Result}

We initial diagnosed this patient with malignant mixed germ cell mediastinal tumor (yolksac and embrinonal carcinoma), patient underwent surgical therapy (surgical sternotomy and tumor debulking) (fig 2) with chemotherapy. The histopathology result from post-surgical debulking showed Schiler-Duval Bodies and large area of necrosis (fig 3). The Chest X-ray evaluation after surgical debulking and chemotherapy showed in fig 4. Patient was given chemotherapy with combination bleomycin, etoposid, cisplatin and evaluated after 3 series chemoteraphy.

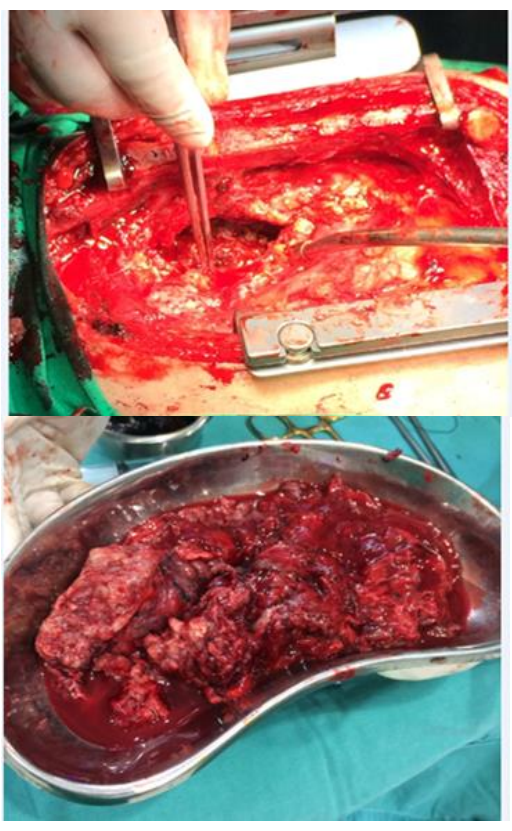

Figure 2. Tumor debulking dan tumor tissue

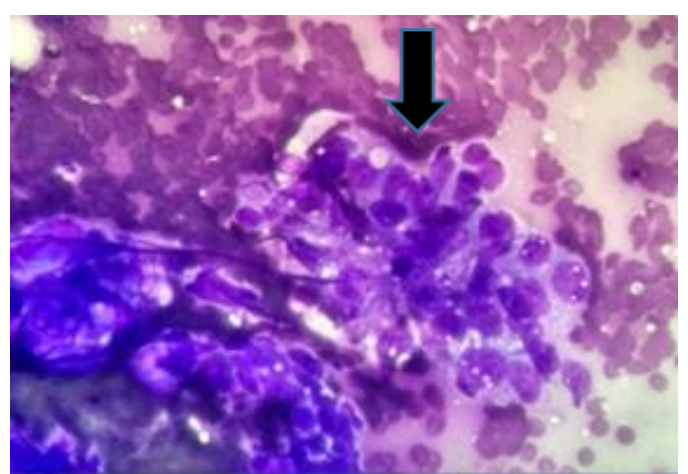

A

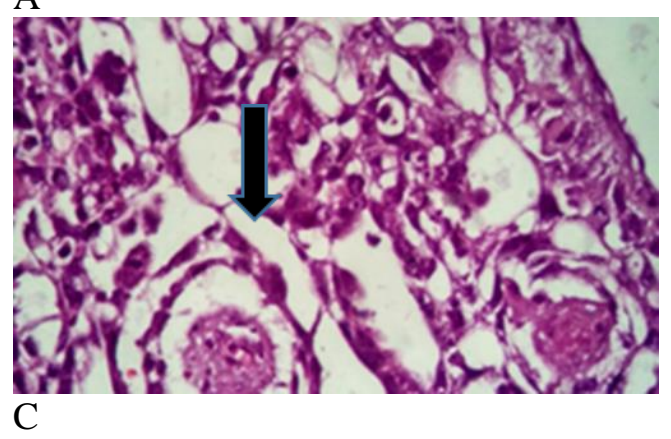

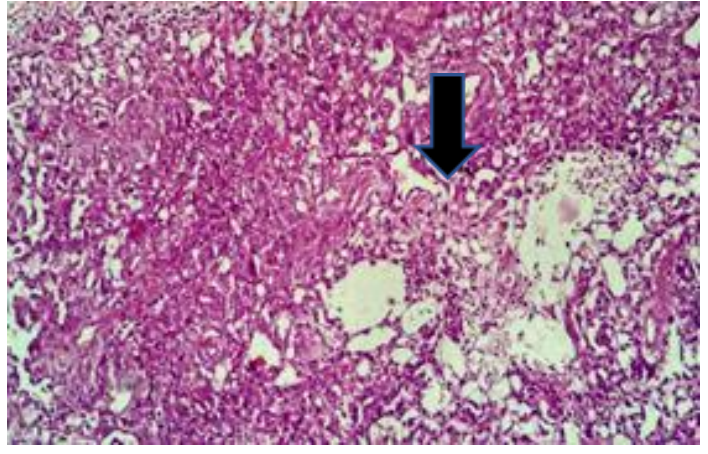

B

Figure 3. Cytology result showed structure cell like adenoca with foam cytoplasma (A); large necrotic different diagnosis squamous cell carcinoma. Schiler-Duval Bodies and large necrosis $(\mathrm{B} \& \mathrm{C})$ 


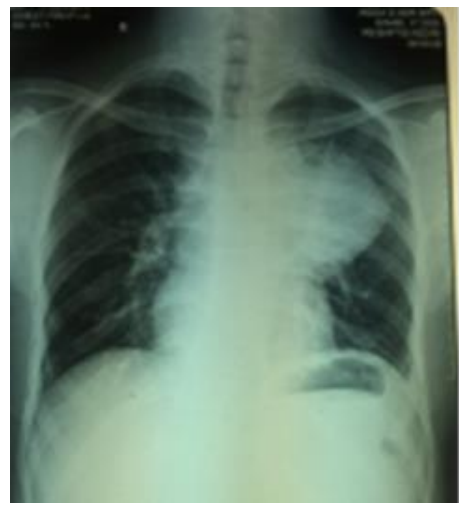

Before surgery

01-06-2017

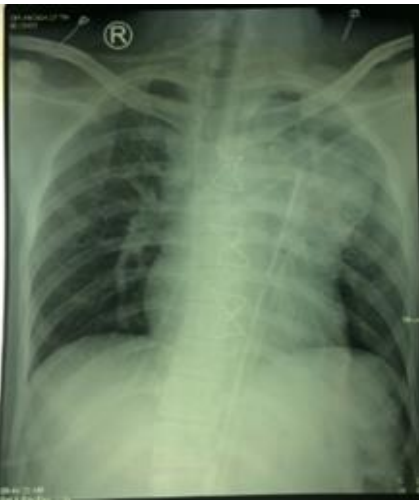

After surgery

20-06-2017

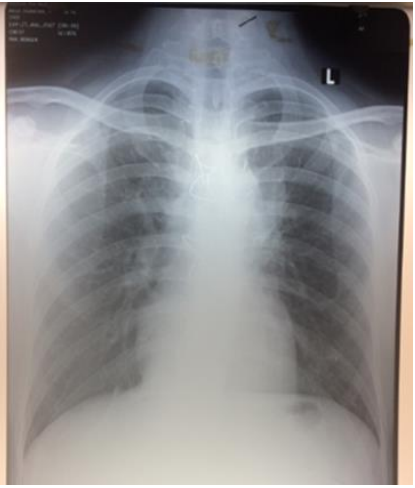

After 3 series chemotherapy

25-08-2017

Figure 4. The Evaluation of the Chest X-Rays After Surgical Debulking and Chemoteraphy

\section{Discussion}

Mixed germ cell tumor is neoplasms consisting of two or more types of germ cell tumor. It's incidence $13-25 \%$ of all mediastinal germ cell tumors. ${ }^{1}$ The biopsy was confirm diagnostic, showed a SchillerDuval bodies and glandular growth pattern. It will be shown $48 \%$ in yolk sac tumor and $66 \%$ in embryonal carcinoma. ${ }^{1}$ Most cases (90\%) show an increase serum tumor marker. Laboratory results have an increase AFP and B-hCG serum. AFP serum over 500 $\mathrm{ng} / \mathrm{ml}$ is a definite diagnosis of Mediastinal Tumor (Non Seminoma Germ Cell Tumor) and correlated with component of yolk sac tumor. ${ }^{5}$ Increase of beta-hCG serum level (30\%) occur in mixed germ cell tumor with choriocarcinoma components syncytiotrophoblast cells. ${ }^{1}$ In this case, patient was given cisplatin, etoposid, and bleomycin chemoteraphy after perfomed surgical debulking. Germ cell tumor therapy depends on cell subtypes and staging of tumor. ${ }^{6}$ Based on NCCN 2017, that case can be given regiment chemoterpahy EP (Etoposid - Cisplatin), BEP (Bleomycin Etoposid - Cisplatin), or VIP (Etoposide Ifosfamide - Cisplatin). ${ }^{7}$ Administration of BEP chemotherapy, showed a mean 5-year survival rate of $>50 \% .{ }^{8}$ The result of the objective evaluation showed chest $\mathrm{x}$-ray after 3 series chemotherapy, tumor size was decreased (complete response). The case of Germ Cell Tumor obtained a complete response of $64 \%$, the possibility of relapses 
$52 \%$ and the worst prognosis among all extragonadal germ cell tumors. ${ }^{9}$

\section{Conclusion}

Patient was confirmed to have malignant mixed germ cell mediastinal tumor (yolksac and embrinonal carcinoma) by clinical symptoms, thoracic CT-scan, tumor marker, histopathology. Patient had been through surgery procedure and 3-series BleomycinEtoposid-Cisplatin chemotherapy, the result of a complete response, asses by the subjective evaluation of reduced chest pain complaints and the objective evaluation of reduce mediastinal mass chest $\mathrm{x}$-rays. Patients should be evaluated for serum tumor markers of AFP and $\mathrm{B}-\mathrm{hCG}$ and evaluation of thorax CT scan every 3-4 months as they are likely to relapse.

\section{Acknowledgments : -}

\section{References}

1. Travis WD, Brambilla E, Burke AP, Marx A, Nicholson AG. Introduction to the 2015 World Health Organization classification of tumors of the lung, pleura, thymus, and heart. Journal of Thoracic Oncology. 2015 Sep 1;10(9):1240-2.
2. Bryant MB, Josep BS. 2015. Beningn and Malignant Neoplasm of the Mediastinum. Fishman's Pulmonary Disease and Disorders.:10th ed, pp. 1259-1273.

3. DeVita VT, Lawrence TS, Rosenberg SA, editors. DeVita, Hellman, and Rosenberg's cancer: principles \& practice of oncology. Lippincott Williams \& Wilkins; 2015.

4. Cameron RB, Loehrer PJ, Thomas Jr CR. 2015. Neoplasma of the Mediastinum DeVita, Hellman \& Rosenberg's Cancer: Principles \& Practice of Oncology. 10th Ed., Lippincott Williams \& Wilkins, USA, p. $560-569$

5. Syahruddin E, Hudoyo A, Jusuf A. 2006. Penatalaksanaan Tumor Mediastinum Ganas.Jurnal Respirologi. (9)

6. Roberts JR, Kaiser LR. 2008. Acquired Lesions of Mediastinum: Benign and Malignant; Fishman's Pulmonary Diseases and Disorders. 4th ED., The McGraw-Hill Companies, USA, p. 1583-1612

7. Motzer, RJ, Jonasch E, Agarwal N, Beard C, Bhayani S, Bolger GB, Chang SS, Choueiri TK, Derwesh IH, Gupta S, Hancock SL. 2016. NCCN Clinical Practice Guidelines1492 in Oncology (NCCN Guidelines) Testicular Cancer. Version 2. 1-15

8. Nakhla SG, Sundrarajan S. 2016. A Rare Case of Primary Anterior Mediastinal Yolk Sac Tumor in an Elderly Adult Male. Case Reports in Oncological Medicine. Departement of meidicine Southern Arizona VA Health care System, USA: 1-5

9. Murphy EM, Douglas JA, Thompson, Wood Lori. 2009. Application of the International Germ Cell Consensus Classification to the Nova Scotia population of Patiens with Germ Cell Tumors. Canadian Urology Association Journal;3(2):120-124 